\title{
On Surface Currents in a Polycrystalline Solar Cell Acting as Ground Plane for Microstrip Patch Antennas
}

\author{
Maria Roo Ons \\ Technological University Dublin \\ S. Shynu \\ Technological University Dublin \\ Max Ammann \\ Technological University Dublin, max.ammann@tudublin.ie
}

See next page for additional authors

Follow this and additional works at: https://arrow.tudublin.ie/engschececon

Part of the Electrical and Computer Engineering Commons

\section{Recommended Citation}

Ons, M. et al. (2008) On surface currents in a polycrystalline solar cell acting as ground plane for microstrip patch antennas. IEEE Antennas and Propagation Society International Symposium, pp.1-4. San Diego, California, 5-11 July, 2008, doi:10.1109/APS.2008.4619749

This Conference Paper is brought to you for free and open access by the School of Electrical and Electronic Engineering at ARROW@TU Dublin. It has been accepted for inclusion in Conference papers by an authorized administrator of ARROW@TU Dublin. For more information, please contact arrow.admin@tudublin.ie, aisling.coyne@tudublin.ie,gerard.connolly@tudublin.ie.

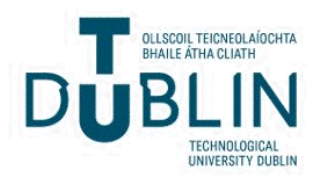


Authors

Maria Roo Ons, S. Shynu, Max Ammann, Sarah McCormack, and Brian Norton

This conference paper is available at ARROW@TU Dublin: https://arrow.tudublin.ie/engschececon/46 


\title{
On Surface Currents in a Polycrystalline Solar Cell Acting as Ground Plane for Microstrip Patch Antennas
}

\author{
Maria J. Roo Ons*(1), Shynu S. V. ${ }^{(1)}$, Max J. Ammann ${ }^{(1)}$, Sarah J. McCormack ${ }^{(2)}$ and \\ Brian Norton ${ }^{(2)}$ \\ (1) School of Electronic and Communications Engineering, Dublin Institute of \\ Technology, Dublin, Ireland \\ (2) Dublin Energy Lab, Focas Institute, Dublin, Ireland \\ E-mail: mariajose.rooons@student.dit.ie
}

\section{Introduction}

The integration of communication devices with Photo Voltaic (PV) technology leads to the development of autonomous communication systems distinguished by immunity to grid break downs and eco-friendliness.

The early interest in combining antennas with solar panels was focused on satellite communications, where antennas and solar cells competed for the same scarce surface on board. The technique first used was the direct placement of solar cell over microstrip patches without covering the radiating edges of the patch [1]. A higher level of integration was then possible with the development of the thin amorphous silicon technology on polymer substrate, enabling the solar cells to be shaped to complex geometries of slot antennas [2].

More recently the radiating patch of a planar antenna was replaced by a solar cell [3]. In such structure, the DC current generation feature of the solar cell remains, but additionally the conductive contacts of the cells are used as part of the radiating structure. Measurements have shown that from an RF point of view a solar cell with a rearside homogeneous contact for DC collection acts almost like a metallic plate.

This principle inspired the use of standard high efficiency polycrystalline cells as ground plane for microstrip antennas. The concept was successfully illustrated by the authors [46], leading to a novel method of integrating a microstrip patch and a standard solar cell, without the need for complex laser cutting [2] nor complex RF-DC decoupling arrangements in the feed [3]. In [6] a common inset-fed microstrip antenna with a solar cell as ground plane was reported. The effects of DC loading, variation in the incident light intensity, and parallel and perpendicular orientations of the solar cell Ag-lines with respect to the patch were discussed. It was shown that parameters such as antenna gain greatly depend on the orientation of the Ag-lines of the solar cell.

In the present work the full wave integral equation based electromagnetic simulator CST Microwave Studio was used to analyze the currents in the cavity between the patch and the rearside of the solar cell, to investigate the antenna dependence on the orientation of the silver grid with respect to the patch. 


\section{Antenna Design}

The basic structure of the inset-fed square patch solar antenna, where the solar cell replaces the standard PEC ground plane is shown in Fig. 1. Both radiating patch and 50ohm transmission line were fabricated on a low cost FR-4 substrate, with a $1.52 \mathrm{~mm}$ thickness and a relative permittivity of 4.3 . The patch dimension is $33.9 \mathrm{~mm} \times 33.9 \mathrm{~mm}$ with the inset-feed inserted at $l=13 \mathrm{~mm}$ and $w=3 \mathrm{~mm}$.

The polycrystalline solar cell is $156 \mathrm{~mm} \times 156 \mathrm{~mm}$ square in size. The rear-side is covered with a thin homogeneous aluminium layer of $35.71 \mu \mathrm{m}$ in thickness, while the front side is gridded with thin silver lines for DC collection, 57 parallel lines $(17.62 \mu \mathrm{m}$ in thickness, $0.1 \mathrm{~mm}$ width) crossed by two $2 \mathrm{~mm}$ major bus bars. In between a $\mathrm{n}^{+}-\mathrm{p}-\mathrm{p}^{+}$ doped silicon layer of thickness $210.23 \mu \mathrm{m}$ is responsible for the inherent potential in the cell when illuminated.

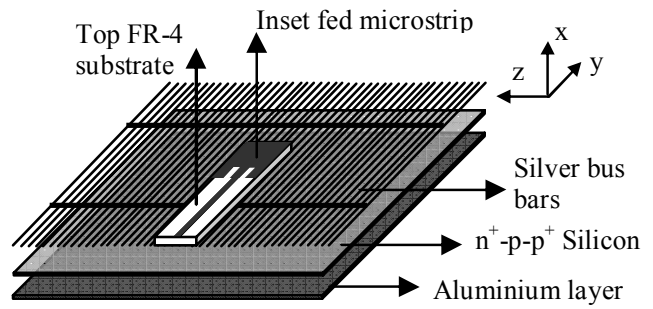

Fig. 1. Exploded layout of the insetfed square patch solar antenna.

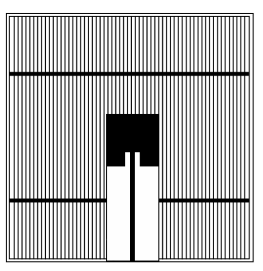

(a)

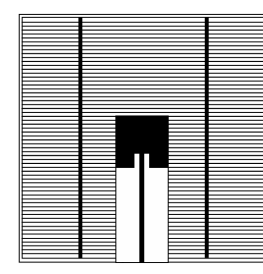

(b)
Fig. 2. Two different line orientations: (a) parallel, (b) perpendicular.

\section{Results and discussion}

A summary of the measured and simulated results for both parallel and perpendicular orientation, as well as for the model with PEC ground, is given in Table I.

\begin{tabular}{ccccccc}
\hline Antenna type & \multicolumn{2}{c}{$\begin{array}{c}\text { Resonant frequency } \\
(\mathrm{GHz})\end{array}$} & \multicolumn{2}{c}{ \% Bandwidth } & \multicolumn{2}{c}{ Gain (dBi) } \\
& Measured & Simulated & Measured & Simulated & Measured & Simulated \\
\hline $\begin{array}{c}\text { Solar antenna } \\
\text { (Ag-parallel) }\end{array}$ & 2.224 & 2.212 & 2.98 & 2.71 & 2.75 & 2.97 \\
$\begin{array}{c}\text { Solar antenna } \\
\quad \text { (Ag- }\end{array}$ & 2.128 & 2.148 & 2.8 & 3.10 & 0.46 & 2.78 \\
$\begin{array}{c}\text { perpendicular) } \\
\text { Ideal patch }\end{array}$ & 2.256 & 2.228 & 2.29 & 2.07 & 3.10 & 3.50 \\
\hline
\end{tabular}

Table I. Measured and simulated performance for both solar and PEC groundplane.

When the thin Ag-lines are parallel to the direction of the resultant electric field vector of the patch, the antenna performance is closer to that of the antenna with PEC groundplane as seen in Table I. In order to justify this, the currents in the cavity formed between the patch and the aluminium layer of the solar cell are investigated.

Fig. 3 shows the currents in the aluminium layer of the polycrystalline solar cell for both parallel and perpendicular arrangements and for the ideal patch with PEC groundplane. 


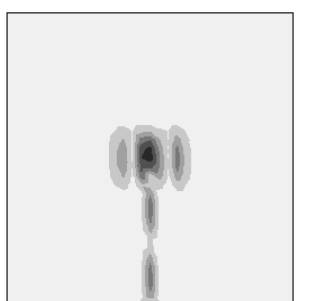

(a)

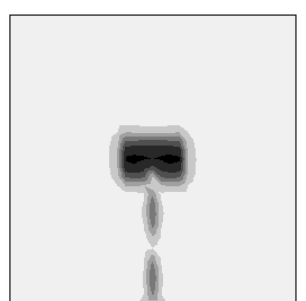

(b)
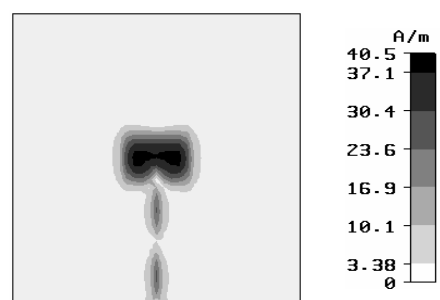

(c)

Fig. 3. Simulated current density in the aluminium layer for the (a) parallel, (b) perpendicular and (c) ideal PEC ground plane.

It can be observed that when the Ag-lines are perpendicular to the resultant electric field, the currents in the aluminium layer of the solar cell are almost as strong as in the PEC ground plane, while for the case of the parallel Ag-lines, they are clearly weaker.

In the case of the PEC ground plane, no other conductors are present in the cavity formed between the microstrip patch and groundplane. When the PEC groundplane is replaced by the polycrystalline solar cell, the homogeneous aluminium rearside contact provides a good ground plane for the patch, but the silver grids exist in the middle of the cavity.

Fig. 4 shows the currents induced in the thin silver lines of the grid for both parallel and perpendicular orientations. The representation in arrows corresponds to each model's maximum. A more zoomed detailed view is pictured in Fig. 5.

From Fig. 3(a), 4(a) and 5(a) it can be observed that most of the current induced in the parallel grid is aligned with the resultant electric field and therefore the penetration into the silicon towards the aluminium layer is minimal. Thus the parallel grid acts as a relatively good reflector.

But when the Ag-lines are oriented perpendicularly to the patch electric field, it is apparent from Fig. 3(b), 4(b) and 5(b) that most of the field penetrates into the lossy silicon layer towards the back Aluminium layer of the cell, which is clearly the strongest reflecting element in the cavity, resulting in the degradation of the solar antenna gain performance as seen in Table I. This phenomenon also explains the lower resonant frequency for this orientation, as the microstrip patch sees an effective increase in substrate height.

Thus, the dependence of the solar antenna parameters on the orientation of the grid is demonstrated, from the analysis of the currents in the silver grid lines and aluminium layer of the solar cell.

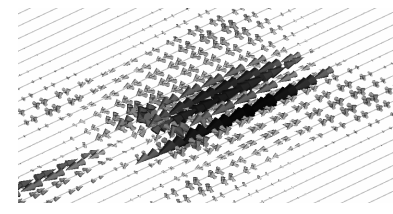

(a)
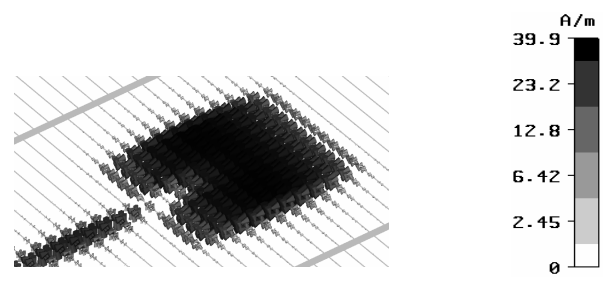

(b)

Fig. 4. Current density in the silver grid lines of the solar cell, for (a) parallel and (b) perpendicular orientations. 


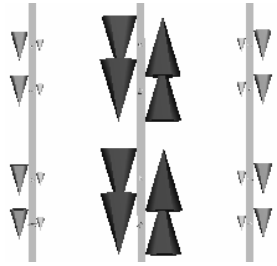

(a)

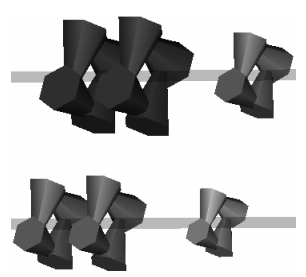

(b)

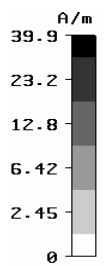

Fig. 5. Detailed vector plot of current density in the silver grid lines of the solar cell, for (a) parallel and (b) perpendicular orientation.

\section{Acknowledgements}

This work was supported by Science Foundation Ireland.

\section{References}

[1] M. Tanaka, Y. Suzuki, K. Araki and R. Suzuki, "Microstrip Antennas with Solar Cells for Microsatellites”, Electron. Lett., vol. 31, pp. 263-266, (1996).

[2] S. Vaccaro, J. R. Mosig, P. de Maagt, "Two Advanced Solar Antenna SOLANT Designs for Satellinte and Terrestrial Communications", IEEE Trans. Antennas Propagat., vol. AP-51, No. 8, pp. 2028-2034, (2000)

[3] C. Bendel, N. Henze, M.Weitz, P. Hofmann, J. Kirchhof, "Investigations on Planar Antennas with Photovoltaic Solar Cells for Mobile communications", IEEE International Symposium on personal, Indoor and Mobile Radio communication (PIMRC), vol.1, pp. 622-626, (2004).

[4] M. J. Roo Ons, Shynu S.V., M. J. Ammann, S. J. McCormack, B. Norton, "Planar Antenna with Integrated Solar Cells for Autonomous Communication Systems", 22nd European Photovoltaic Solar Energy Conference and Exhibition (EU PVSEC), Proceedings CD, pp.333-336, Milan (September, 2007).

[5] M. J. Roo Ons, Shynu S.V., M. J. Ammann, S. J. McCormack, B. Norton, "Investigation on Proximity-Coupled Microstrip Integrated PV Antenna", The Second European Conference on Antennas and Propagation (EuCAP), Edinburgh (November, 2007).

[6] Shynu S.V., M. J. Roo Ons, M. J. Ammann, S. J. McCormack, B. Norton, "Inset-Fed Microstrip Patch Antenna with Integrated Polycrystalline Photovoltaic Solar Cell", The Second European Conference on Antennas and Propagation (EuCAP), Edinburgh (November, 2007). 